\title{
Development of muffins as dialysis snacks for patients undergoing hemodialysis: results of chemical composition and sensory analysis
}

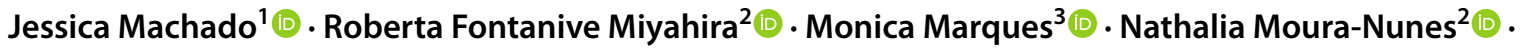

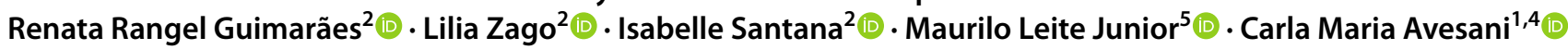

Received: 30 April 2020 / Accepted: 8 August 2020 / Published online: 28 August 2020

(C) The Author(s) 2020

\begin{abstract}
Objective This study aimed to develop two non-industrial food products as financially accessible options to prevent and treat malnutrition in hemodialysis (HD) patients. These food products were developed and intended for use as dialysis snacks.

Methods This is a cross-sectional and multi-step study. First, 183 adult HD patients ( $55 \pm 14$ years; $50.8 \%$ males), replied to a questionnaire with their food preferences regarding taste (salty, sweet, bitter, sour) and consistency (liquid, solid, pasty) for a dialysis snack. Most patients preferred a food product with a solid consistency (90\%) and a salty flavor (81.4\%). Second, three muffin formulations of fine herbs were developed; one enriched with whey protein concentrate (WPC), a second with textured soy protein (TSP) and a third standard formulation without protein for comparison with the protein-enriched muffins, for which the chemical and nutritional compositions were analyzed. In the third step, 60 patients on HD (61 \pm 15 years; 53\% males) were enrolled in a sensory analysis by applying a 9-point structured hedonic scale, ranging from "extremely liked" (score 9) to "extremely disliked" (score 1).

Results When compared with the standard formulation, the formulations enriched with WPC and TSP protein had a significantly higher amount of protein/serving (Standard: $5.9 \pm 0.3 \mathrm{~g}$ vs WPC: $14.5 \pm 0.9 \mathrm{~g}$ and TSP $10.8 \pm 0.7 \mathrm{~g} ; \mathrm{P}<0.05$ ) but a lower amount of carbohydrate (Standard: $13.1 \pm 2.2 \mathrm{~g}$ vs WPC: $5.6 \pm 0.8 \mathrm{~g}$ and TSP $6.0 \pm 1.2 \mathrm{~g} v \mathrm{vs} ; \mathrm{P}<0.05$ ). The mineral content/serving of the protein-enriched muffins was low in phosphorus $(50 \mathrm{mg})$ and sodium $(180 \mathrm{mg})$. The potassium content/ serving was moderate for the WPC muffin $(225.2 \mathrm{mg}$ ) and low for the TSP muffin $(107.9 \mathrm{mg})$. The acceptability index (AI) for the enriched protein muffins was higher than $70 \%$ and similar to the standard formulation.

Conclusion The muffins with fine herbs and enriched with protein were well-accepted by all patients and appropriate to serve as dialysis snacks for HD patients.
\end{abstract}

Keywords Hemodialysis · Dialysis snack · Protein energy wasting · Energy protein supplement

Carla Maria Avesani

carla.avesani@ki.se

1 Graduation Program in Food, Nutrition and Health, Institute of Nutrition, Rio de Janeiro State University, R São Francisco Xavier, 524, Rio de Janeiro, RJ 20550-900, Brazil

2 Department of Basic and Experimental Nutrition, Institute of Nutrition, Rio de Janeiro State University, R Sao Francisco Xavier, 524, Rio de Janeiro 20550-900, Brazil

3 Department of Organic Chemistry, Institute of Chemistry, Rio de Janeiro State University, R Sao Francisco Xavier, 524, Rio de Janeiro 20550-90, Brazil

4 Department of Clinical Science, Intervention and Technology, Division of Renal Medicine, Baxter Novum, Karolinska Institute, M99 Karolinska University Hospital Huddinge, Huddinge 14186, Sweden

5 Nephrology Division, Rio de Janeiro Federal University, Av Pedro Calmon, 550, Rio de Janeiro 21941-901, Brazil

\section{Introduction}

Malnutrition is a prevalent condition in patients with chronic kidney disease (CKD) undergoing dialysis. According to a recent meta-analysis including studies from several countries, in which malnutrition has been diagnosed either by the 7-point subjective global assessment (SGA-7p) or the malnutrition inflammation score (MIS), 28-54\% of the dialysis patients had malnutrition [1]. The etiology of malnutrition is multifactorial, including disease and treatment-related factors that, together, create a condition where reduced energy and protein intake are concomitantly observed, with increased protein catabolism and energy expenditure [2]. This particular condition led the expert panel of the International Society in Renal Nutrition and Metabolism (ISRNM) 
to use the term protein energy wasting (PEW) to describe the nutritional disorder that occurs in CKD [3]. Importantly, Ikizler et al. [4] have shown that energy expenditure and protein degradation increase substantially during and after a 2-h hemodialysis (HD) session, leading to a negative energy and protein balance. In a subsequent study, the same group showed that intradialytic oral energy-protein supplementation was capable of reversing the acute energy and protein catabolism effect caused by the dialysis procedure [5]. These findings reinforce the importance of providing energy and protein support to attenuate the protein catabolism that occurs during and after HD.

Several studies have shown the effectiveness of industrial oral nutrition supplements $[6,7]$ in order to compensate for the reduced food intake, reported mainly on HD days [8-10]. In addition, a potential benefit of oral supplementation to increase survival $[6,11]$ and to decrease missed HD treatments [6] has also been documented. Nevertheless, the use of industrial intradialytic oral supplementation is not feasible for many dialysis centers due to its high cost for longterm use. Moreover, low adherence to such supplements has been reported, likely due to the monotony of taste and flavor [12]. In this sense, non-industrial supplements that can be prepared by the patient, family or caregivers are likely to confer advantages for long-term use, in addition to allowing for more independence in the treatment and greater dietary flexibility.

The present study set out to develop two food products with high energy and protein density, whilst remaining moderate in potassium $(\mathrm{K})$, phosphorus $(\mathrm{P})$ and sodium $(\mathrm{Na})$, and that could be made using reasonably-priced ingredients. Such products could be feasible and affordable options for use as dialysis snacks to both prevent and treat PEW in HD patients.

\section{Methods}

\section{Study design and protocol}

This is a cross-sectional study including two samples of adult patients (aged $\geq 18$ years) undergoing chronic HD treatment, on a regular 3 sessions-per-week schedule for at least 3 months, from two dialysis centers located in Rio de Janeiro, Brazil. The first sample was made up of 183 adult patients (mean age $54.9 \pm 14.1$; male $\mathrm{n}=93,50.8 \%$; body mass index (BMI) $25 \pm 5.1 \mathrm{~kg} / \mathrm{m}^{2}$ ) and aimed at investigating the food preferences of a representative sample of HD patients in order to formulate a food product aligned with their particular likes and preferences. These patients replied to a food questionnaire about their preferences regarding food consistency and taste. With the results of this questionnaire, two food products were developed in order to be suitable for use as a dialysis snack. The second sample was made up of 60 patients (mean age $60.5 \pm 15.2$; male $n=32$, $53 \%$; BMI $23.6 \pm 4.3 \mathrm{~kg} / \mathrm{m}^{2}$ ) from another dialysis center, who in addition to the inclusion criteria as described above, had serum albumin $<4.0 \mathrm{~g} / \mathrm{dL}$. This group participated in a sensory analysis of the developed food products. Considering that these products contained no added sugar, diabetic patients were included, but patients with gluten and/or lactose intolerance or allergies were not. Figure 1 describes the study design, protocol and patient selection.

The study protocol was approved by the Research Ethics Committee (Pedro Ernesto University Hospital, Rio de Janeiro State University, number 2.259.878). All procedures were in compliance with the principles of the Declaration of Helsinki. Informed consent was obtained from each of the participants of this study.

\section{Food products}

The results of the food questionnaire administered to 183 HD patients are shown in Table 1 and indicate a preference for a product of solid consistency with a salty taste. Therefore, two muffin formulations of fine herbs, one enriched with whey protein concentrate (WPC) and a further muffin with textured soy protein (TSP) were developed. Both formulations were devised with limited content of $\mathrm{K}, \mathrm{P}$ and $\mathrm{Na}$, and were developed at the Institute of Nutrition (Rio de Janeiro State University, Brazil). The chemical composition and nutritional composition of the muffins were analyzed at the Institute of Chemistry (Rio de Janeiro State University, Brazil).

In order to compare the protein-enriched muffins with a standard muffin and investigate whether the protein-enriched muffin would show different acceptance from the standard formulation, a muffin formulation without protein was developed $\left(\mathrm{M}_{\text {Standard }}\right)$. The formulations enriched with either WPC or TSP were developed by replacing $1 / 3$ of the wheat flour with a protein base $\left(\mathrm{M}_{\mathrm{WPC}}\right.$ and $\left.\mathrm{M}_{\mathrm{TSP}}\right)$. All ingredients were manually mixed, homogenized and oven baked at $220{ }^{\circ} \mathrm{C}$ for $30 \mathrm{~min}$. The muffins were prepared according to the formulations shown in Table 2.

\section{Chemical composition of the muffins}

The moisture, ash, fat and protein contents of the muffins were determined according to the Association of Official Analytical Chemists (AOAC) [13], while carbohydrate was determined by difference [14]. Briefly, the moisture was oven dried at $105{ }^{\circ} \mathrm{C}$ to constant weight, while ash was determined by incineration of the samples in a muffle furnace at $550{ }^{\circ} \mathrm{C}$ to constant weight. Fat was determined using the Soxhlet method followed by evaporation to constant weight and protein was analyzed using the Kjeldahl method with a 


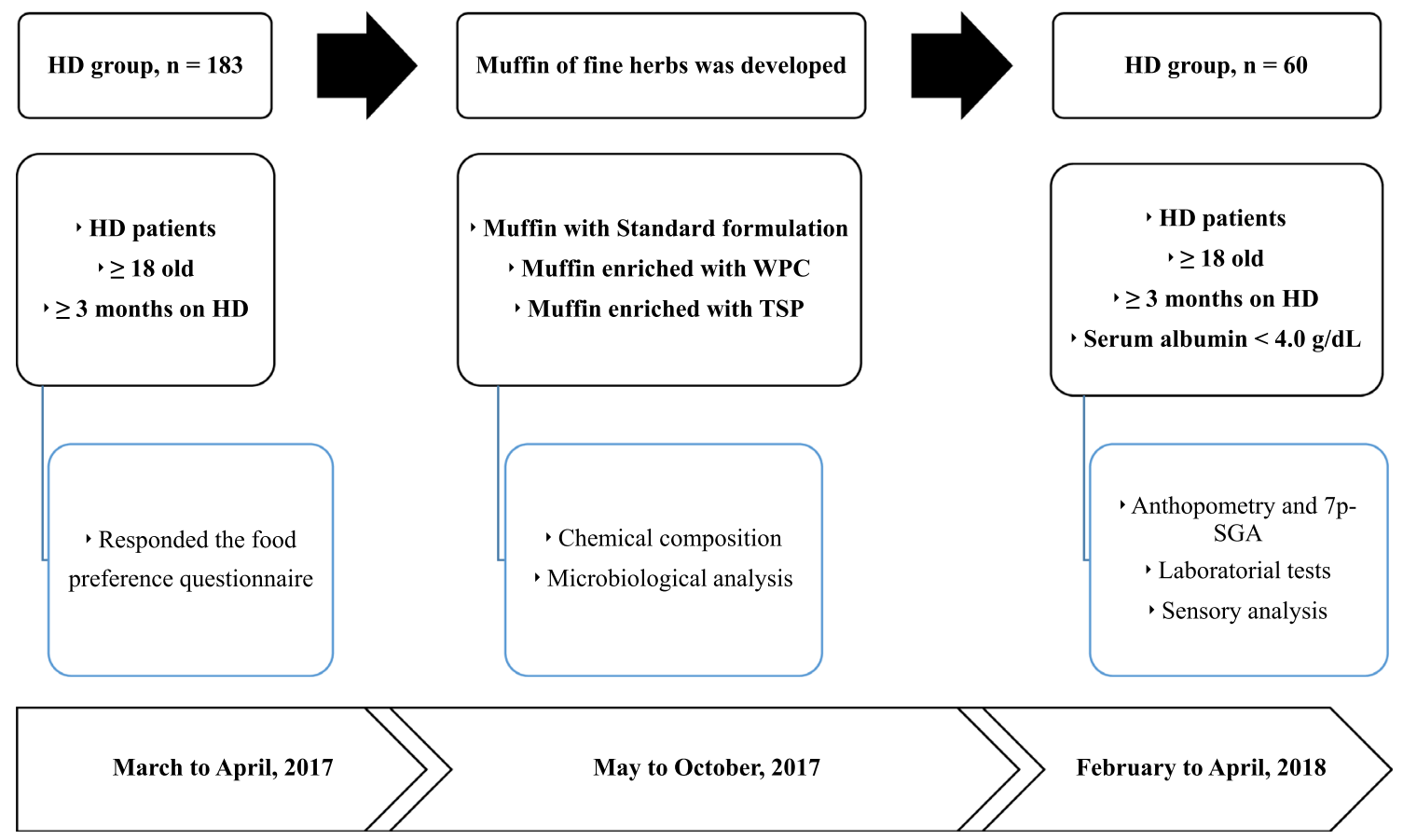

HD: hemodialysis, WPC: whey protein concentrate, TSP: textured soy protein; 7p-SGA: 7 point subjective global assessment

Fig. 1 Study protocol describing patient selection, development of the muffins and sensory analysis

Table 1 Results of the food preferences questionnaire of adult patients undergoing chronic hemodialysis $(\mathrm{n}=183)$

\begin{tabular}{ll}
\hline Variable & $\mathrm{n} ; \%$ \\
\hline Food consistency & \\
Solid & $166 ; 90.7$ \\
Liquid & $1 ; 0.6$ \\
Pasty & $16 ; 8.7$ \\
Flavor & \\
Salty & $149 ; 81.4$ \\
Sweet & $34 ; 18.6$ \\
\hline
\end{tabular}

conversion factor of 5.7 (wheat), 6.25 (soy) or 6.38 (milk) [13].

Finally, P, K and Na from refined wheat, WPC and TSP were determined by inductively coupled plasma mass spectrometry according to the methodology of the Adolfo Lutz Institute [15]. All analyses were performed in triplicate for the process and sample. The mineral content of the remaining ingredients was obtained from the Brazilian Table of Food Composition (TACO) [16].

\section{Nutritional status}

The group of patients enrolled in the sensory analysis $(n=60)$ had their nutritional status assessed by body weight and height, SGA-7p and serum albumin. The SGA-7p,
Table 2 Ingredients of standard muffin, muffin added with whey protein concentrate and muffin added with textured soy protein

\begin{tabular}{llll}
\hline Ingredients & $\mathrm{M}_{\text {Standard }}$ & $\mathrm{M}_{\mathrm{WPC}}$ & $\mathrm{M}_{\mathrm{TSP}}$ \\
\hline Refined wheat flour $(\mathrm{g})$ & 150 & 100 & 100 \\
Whey protein concentrate $(\mathrm{g})$ & - & 50 & - \\
Textured soy protein $(\mathrm{g})$ & - & - & 50 \\
Baking powder $(\mathrm{g})^{\mathrm{A}}$ & 5 & 5 & 5 \\
Herbs $^{\mathrm{A}}(\mathrm{g})$ & 2.5 & 2.5 & 2.5 \\
Fresh garlic (g) & 2.5 & 2.5 & 2.5 \\
Refined salt (g) & 1 & 1 & 1 \\
Egg (g) & 100 & 100 & 100 \\
Whole milk (mL) & 70 & 70 & 70 \\
Soy oil (mL) & 50 & 50 & 50 \\
\hline
\end{tabular}

$M_{\text {Standard }}$ muffin standard, $M_{W P C}$ muffin with whey protein concentrate, $M_{T S P}$ muffin with textured soy protein

${ }^{\mathrm{A}}$ Herbs: Mix of dehydrated parsley, chives, tarragon, rosemary and thyme

translated and validated to Portuguese, was used [17], and patients were classified as well-nourished (score 7-6), mild to moderate malnutrition (score 5-3) and severe malnutrition (score 2-1). The same trained dietitian performed both the anthropometric measurements and the SGA-7p. 


\section{Laboratory analysis}

Blood samples for laboratory tests were taken in the midweek dialysis session. Serum urea (pre and post dialysis for Kt/V calculation), creatinine, albumin, potassium and phosphorus were evaluated for patients who participated in the sensory analysis $(n=60)$. Serum albumin was analyzed by the bromocresol green method.

\section{Sensory analysis}

Acceptance of the muffins was assessed by applying an affective test, using the 9-point structured hedonic scale which ranged from "extremely liked" (score 9) to "extremely disliked" (score 1). Appearance, texture, taste and overall acceptance were the sensory attributes evaluated. The patients received one sample (10 g) of each muffin (WPC, TSP and Standard) coded with three random digits in order to prevent identification. Sensory analysis of the three products occurred separately and, between each of the tastings, a glass of water $(50 \mathrm{ml})$ was offered to minimize the residual taste of the previous sample.

The results are expressed as the mean score for each attribute and the acceptance index (AI) was calculated as follows: AI $(\%)=A^{*} 100 / B$, where A was the mean score obtained for each formulation and $\mathrm{B}$ was the maximum score obtained [15]. The muffin formulations with a higher than $70 \%$ AI were well accepted [18]. The intention of consumption was also performed using a 5-point scale ranging from "I would certainly eat it" (score 5) to "I would never eat it" (score 1).

\section{Statistical analysis}

Data are described as mean \pm standard deviation, or as median and interquartile range, as appropriate, depending on the variable distribution. Categorical variables are shown as absolute values and respective percentage. Comparison of the chemical and sensory composition between the standard muffin and the protein-enriched muffins was performed by analysis of variance (ANOVA) for independent samples, with post-hoc Bonferroni or the Kruskal-Wallis test, depending on the distribution of the variable. The chi-square test was used to compare categorical variables. The statistical tests were performed using the Statistical Package for the Social Sciences (SPSS) version 23 (Inc., Chicago, IL, USA) and a P value $<0.05$ was considered statistically significant.

\section{Results}

The muffins are shown in Fig. 2 and their chemical composition is listed in Table 3. No differences were observed in the moisture, ash, fat content or energy values among the
3 muffins. As expected, the protein content of the proteinenriched muffins ( $\mathrm{M}_{\mathrm{WPC}}$ and $\left.\mathrm{M}_{\mathrm{TSP}}\right)$ was significantly higher than that of the $\mathrm{M}_{\text {Standard }}$, with the $\mathrm{M}_{\mathrm{WPC}}$ showing the highest protein content. Moreover, the carbohydrate content of the protein-enriched muffins ( $\mathrm{M}_{\mathrm{WPC}}$ and $\left.\mathrm{M}_{\mathrm{TSP}}\right)$ was significantly lower than that of $\mathrm{M}_{\text {Standard. }}$. The mineral content proved adequate for HD patients, according to the CKD nutrition guidelines $[19,20]$. The $\mathrm{K}, \mathrm{P}$ and $\mathrm{Na}$ content per serving of the $\mathrm{M}_{\text {Standard }}$ were $83.5 \mathrm{mg}, 48.2 \mathrm{mg}$ and $183.2 \mathrm{mg}$, respectively; for the $\mathrm{M}_{\mathrm{WPC}}$ these values were $107.9 \mathrm{mg}, 48.9 \mathrm{mg}$ and 183.4 , respectively; and for the $\mathrm{M}_{\mathrm{TSP}}$ they were $225.2 \mathrm{mg}$, $49.6 \mathrm{mg}$ and $183.2 \mathrm{mg}$ respectively. The estimated cost of one serving of the enriched protein muffins was USD $\$ 0.50$ cents (estimated in August of 2018).

Table 4 describes the demographic, clinical and nutritional characteristics of the HD patients that participated in the sensory analysis. In general, males and females were equally distributed, $60 \%$ of the patients had some degree of malnutrition according to SGA, and the mean serum albumin was below $3.8 \mathrm{mg} / \mathrm{dL}$. In addition, mean serum $\mathrm{K}$ and $\mathrm{P}$ were within normal range, but $45 \%$ of the patients had hyperkalemia (serum $\mathrm{K}>5 \mathrm{mEq} / \mathrm{L}$ ) and $28 \%$ had hyperphosphatemia (serum $\mathrm{P}>5 \mathrm{mg} / \mathrm{dL}$ ). Regarding the sensory analysis, the results are shown in Table 5. All formulations were well-accepted with regard to the attributes of appearance, texture and taste, and the overall acceptance scored above 7, thus indicating good acceptance. No statistical difference between the formulations was observed. Moreover, the acceptability index was higher than $70 \%$ for all attributes. The results of the intention of consumption showed that $85 \%, 83.3 \%$ and $78.3 \%$ of the patients rated the $\mathrm{M}_{\mathrm{WPC}}$, $\mathrm{M}_{\text {Standard }}$ and $\mathrm{M}_{\mathrm{TSP}}$, respectively, as "I would certainly eat it".

\section{Discussion}

This study aimed to develop food products with high amounts of energy and protein whilst being moderate to low in $\mathrm{K}, \mathrm{P}$ and $\mathrm{Na}$ to meet the nutritional needs of $\mathrm{HD}$ patients, mainly those facing nutritional risk or those who are malnourished. In addition, in order to be suitable as a dialysis snack, we also aimed to develop food products that could further be produced as "home-made", and at an affordable cost. After administering a food preference questionnaire, in which patients reported their preference for salty and solid food, a muffin with fine herbs was developed with two sources of protein, WPC and TSP, aimed at reaching two price ranges. The results pertaining to the chemical composition of the muffins showed that, compared to the $\mathrm{M}_{\text {Standard }}$, the $\mathrm{M}_{\mathrm{WPC}}$ and $\mathrm{M}_{\mathrm{TSP}}$ had significantly higher protein content, whilst retaining an adequate amount of $\mathrm{K}, \mathrm{P}$ and $\mathrm{Na}$ for dialysis patients. Particularly with regard to $\mathrm{K}$, the $\mathrm{M}_{\mathrm{TSP}}$ yielded slightly over $200 \mathrm{mg} / \mathrm{serving}(225.2 \mathrm{mg}$ ), 
Fig. 2 Muffins of fine herbs developed for patients undergoing chronic hemodialysis and used in the sensory analysis. a Standard Muffins (not enriched with protein). b Muffins enriched with whey protein concentrate. c Muffins enriched with textured soy protein
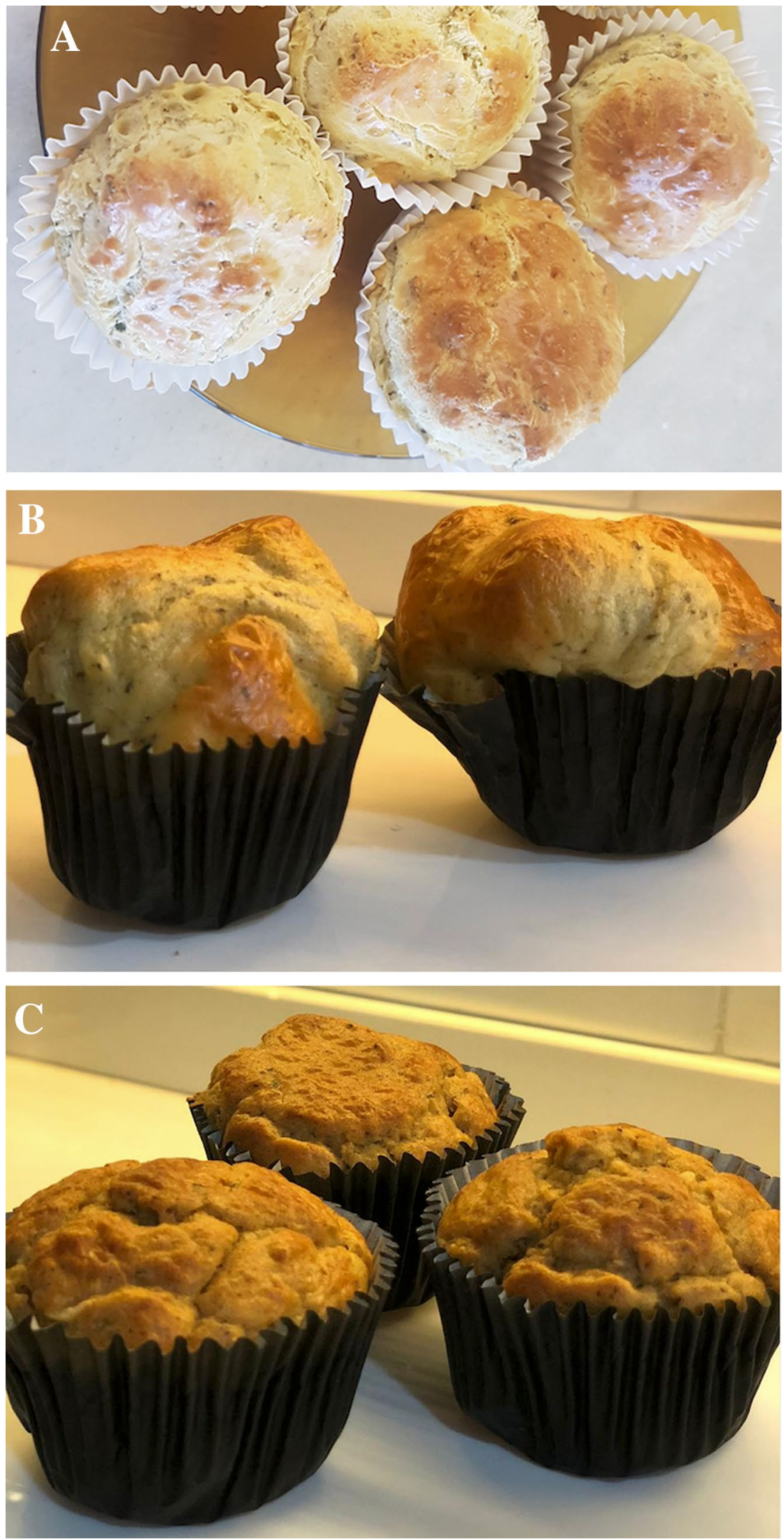
Table 3 Chemical composition of the muffins

\begin{tabular}{|c|c|c|c|c|}
\hline \multirow[t]{2}{*}{ Composition } & \multicolumn{4}{|c|}{ Muffins (one serving $=60 \mathrm{~g}$ ) ${ }^{\mathrm{A}}$} \\
\hline & $\begin{array}{l}\mathrm{M}_{\text {Standard }} \\
\text { Mean } \pm \mathrm{SD}\end{array}$ & $\begin{array}{l}\mathrm{M}_{\mathrm{WPC}} \\
\text { Mean } \pm \mathrm{SD}\end{array}$ & $\begin{array}{l}\mathrm{M}_{\mathrm{TSP}} \\
\text { Mean } \pm \mathrm{SD}\end{array}$ & $\begin{array}{l}\text { One-way ANOVA } \\
\text { ( } P \text { value) }\end{array}$ \\
\hline Moisture (g) & $19.9 \pm 1.0$ & $20.9 \pm 1.1$ & $20.5 \pm 0.1$ & 0.41 \\
\hline Ash (g) & $1.7 \pm 0.2$ & $1.8 \pm 0.2$ & $2.1 \pm 0.2$ & 0.08 \\
\hline Energy (Kcal) & $213 \pm 2.9$ & $208 \pm 11.8$ & $216 \pm 2.7$ & 0.41 \\
\hline Protein $(\mathrm{g})$ & $5.9 \pm 0.3^{\mathrm{a}}$ & $14.50 .9^{\mathrm{b}}$ & $10.8 \pm 0.7^{\mathrm{c}}$ & $<0.001$ \\
\hline Fat $(\mathrm{g})$ & $15.3 \pm 1.2$ & $14.2 \pm 1.2$ & $16.6 \pm 0.4$ & 0.08 \\
\hline Carbohydrate (g) & $13.1 \pm 2.2^{\mathrm{a}}$ & $5.6 \pm 0.8^{\mathrm{b}}$ & $6.0 \pm 1.2^{\mathrm{b}}$ & 0.002 \\
\hline Potassium (mg) ${ }^{\mathrm{A}}$ & 83.5 & 107.9 & 225.2 & NA \\
\hline Phosphorus (mg) ${ }^{\mathrm{B}}$ & 48.2 & 48.9 & 49.6 & NA \\
\hline Sodium $(\mathrm{mg})^{\mathrm{B}}$ & 183.2 & 183.4 & 183.2 & NA \\
\hline
\end{tabular}

$M_{\text {Standard }}$ muffin standard, $M_{W P C}$ muffin with whey protein concentrate, $M_{T S P}$ muffin with textured soy protein, $N A$ not applicable, $S D$ standard deviation, ANOVA one-way analysis of variance analysis with Bonferroni post-hoc test

Different letters on the same line indicate statistical difference $(\mathrm{p}<0.05)$

${ }^{\mathrm{A}}$ Analysis carried out in triplicate

${ }^{B}$ Value from the Brazilian Food Composition Table
Table 4 Demographic, clinical and nutritional characteristics of the hemodialysis patients that participated in the sensory analysis $(n=60)$

\begin{tabular}{ll}
\hline Variable & Values $^{\mathrm{a}}$ \\
\hline Male (n; \%) & $32(53)$ \\
Age (years) & $60.5 \pm 15.2$ \\
DM (n; \%) & $13(22)$ \\
Urea Kt/V & 1.70 .43 \\
BMI $\left(\mathrm{kg} / \mathrm{m}^{2}\right)$ & $23.6 \pm 4.3$ \\
$7 \mathrm{p}-\mathrm{SGA}$ & $5.2 \pm 1$ \\
Malnourished $(\mathrm{n} ; \%)$ & $36(60)$ \\
Serum urea $(\mathrm{mg} / \mathrm{dL})$ & $113(97-140)$ \\
Serum creatinine $(\mathrm{mg} / \mathrm{dL})$ & $8.3(6.6-11.1)$ \\
Serum albumin $(\mathrm{g} / \mathrm{dL})$ & $3.6 \pm 0.3$ \\
Serum potassium $(\mathrm{mEq} / \mathrm{L})$ & $5.0 \pm 0.8$ \\
Serum phosphate $(\mathrm{mg} / \mathrm{dL})$ & $4.2(3.8-5.1)$ \\
\hline
\end{tabular}

$D M$ diabetes mellitus, $K t / V$ dialyzer urea clearance, $B M I$ body mass index, $7 p$-SGA 7 point Subjective Global Assessment

${ }^{a}$ Values described as mean and standard deviation or as median and interquartile interval or as absolute values and respective percentage

${ }^{\mathrm{b}}$ Malnourished: diagnosed by SGA-7p $\leq 5$ which is higher than that normally accepted for low $\mathrm{K}$ food ( $<200 \mathrm{mg} / \mathrm{serving}$ ) according to the Nutrition Kidney Disease Outcomes Quality Initiative guidelines (KDOQI) [20]. In the current study, $45 \%$ of the patients that participated in the sensory analysis had hyperkalemia (serum $\mathrm{K}>5 \mathrm{mEq} / \mathrm{L}$ ). Likewise, a lower prevalence of hyperphosphatemia (serum P $>5 \mathrm{mg} / \mathrm{dL}$ ) was observed (28\%). These findings suggest that the majority of patients would not need to restrict food sources of $\mathrm{K}$ and $\mathrm{P}$ when planning an intervention to treat malnutrition. However, if malnutrition and these mineral abnormalities coexist, restriction of food sources of $\mathrm{K}$ and $\mathrm{P}$ is to be adopted only where an excessive intake of these minerals is present. Particularly for the use of the muffins herein presented, the $\mathrm{M}_{\mathrm{WPC}}$ is preferable to the $\mathrm{M}_{\mathrm{TSP}}$ in case of hyperkalemia, and since the $\mathrm{P}$ content was low, both muffins can be recommended even if hyperphosphatemia occurs. In terms of cost, two servings of the enriched protein muffins cost about half as much, but have the energy and content close to that of an industrialized food supplement, rich in energy and protein and moderate in $\mathrm{Na}, \mathrm{K}$ and $\mathrm{P}$. Of further importance, the sensory analysis of both enriched
Table 5 Sensory analysis and acceptability index of the muffins

\begin{tabular}{lllllllll}
\hline Sensory Attributes & \multicolumn{3}{c}{ Accepted test (mean $\pm \mathrm{SD})$} & & \multicolumn{3}{c}{ Acceptability index (\%) } \\
\cline { 2 - 3 } & $\mathrm{M}_{\text {Standard }}$ & $\mathrm{M}_{\mathrm{WPC}}$ & $\mathrm{M}_{\mathrm{TSP}}$ & $P^{*}$ & & $\mathrm{M}_{\text {Control }}$ & $\mathrm{M}_{\mathrm{WPC}}$ & $\mathrm{M}_{\mathrm{TSP}}$ \\
\hline Appearance & $7.2 \pm 1.9$ & $7.2 \pm 1.8$ & $7.1 \pm 2.1$ & 0.44 & 80 & 81 & 79 \\
Texture & $7.4 \pm 1.9$ & $7.3 \pm 1.8$ & $7.2 \pm 2.1$ & 0.35 & & 82 & 80 & 79 \\
Taste & $7.4 \pm 1.8$ & $7.2 \pm 1.8$ & $7.0 \pm 2.2$ & 0.54 & & 82 & 80 & 78 \\
Overall acceptance & $7.4 \pm 1.9$ & $7.2 \pm 1.8$ & $7.0 \pm 2.1$ & 0.59 & & 82 & 85 & 78 \\
\hline
\end{tabular}

$S D$ standard deviation, $M_{\text {Standard }}$ control muffin, $M_{W P C}$ muffin with whey protein concentrate, $M_{T S P}$ muffin with textured soy protein

$P^{*}$ ANOVA test (analysis of variance) for paired samples 
protein muffins, as reported by $60 \mathrm{HD}$ patients, showed that the muffins were well-accepted with regard to appearance, texture and taste, in addition to having a high overall index of acceptance, acceptability and a high percentage of intention of consumption. Our results confirm that these products are suitable, low-cost options for HD patients. Although the recommendation of this muffin should be individualized by the dietitian on the basis of nutritional status, appetite, tolerance and overall clinical condition of each patient, it is likely that for a patient with malnutrition on HD, two muffins per dialysis session would be adequate. As a way of stimulating healthier options that are adequate for dialysis snacks, patients who participated in the current study received a folder with the recipe and nutritional content of the muffins. Therefore, initiatives like the one presented here, that motivate patients to find "ultra-processed and additive-free" options, with recipes that can be home-made, and with educational activities that develop cooking skills, such as preparing these muffins, are important in order to motivate a healthier dietary quality and more independence in the dietary treatment. Such initiatives are aligned with those recommended by the food guide of the Brazilian population [21] and by the Italian Society of Nephrology, which include healthy lifestyle and diet [22]. This becomes more relevant when one considers that HD is a chronic and long-term treatment, and that patient involvement in his/her own treatment is key for a better outcome.

As has been well documented worldwide, the prevalence of malnutrition in HD patients, assessed by SGA-7p or MIS, ranges from 28 to $54 \%$ [1]. In the present study, $60 \%$ of patients had some degree of malnutrition as assessed by SGA-7p, a prevalence higher than that reported above, justified by the inclusion criteria of the current study—serum albumin $<4 \mathrm{~g} / \mathrm{dL}$, to select patients at nutritional risk or with malnutrition. Therefore, the patients included in the sensory analysis would show more benefit from food initiatives with increased energy and protein amounts. As is well-known and has been demonstrated, malnutrition is highly associated with poor quality of life [23, 24], increased hospitalization rates $[24,25]$ and higher all-case and cardiovascular mortality [24-30] Since increasing energy and protein intake is a recognized approach to treating malnutrition, strategies as the one from the current study are relevant for the clinical practice of dietitians working with end-stage kidney disease (ESKD) patients, especially because industrialized supplements are not always feasible for all patients in dialysis centers. This result shows the importance of developing food products that can increase the options of intradialytic supplementation and that match with the patient's food preferences. Therefore, our findings regarding the preference for salty and solid snacks, which is the opposite of the characteristics of industrialized supplements that tend to be sweet and of liquid consistency, are of interest in order to explore food products with a higher chance of acceptability and adherence for long term use. This led us to develop a bakery product that has the advantage of being well-accepted worldwide, except for those patients with gluten intolerance. Moreover, in order to avoid flavor monotony; varying the types of herbs and spices, such as oregano, rosemary, dill, tarragon, cumin, garlic, paprika and onion, among others, can be used without compromising the energy, protein, $\mathrm{Na}, \mathrm{K}$ and $\mathrm{P}$ content of the muffins. Other studies that developed non-industrialized food products for HD, although scarce, showed promising results in improving the nutritional status of patients that were malnourished [31-34].

Roy et al. [31] developed a cookie that contained ingredients from the local culture (India), containing soy protein isolate as the protein source. Compared to the standard cookie, the cookie developed in the study contained approximately $25 \%$ more fat than the standard, and $9 \mathrm{~g}$ of protein $/ 100 \mathrm{~g}$ [31]. After an intervention with three cookies per day for 3 months, which provided $590 \mathrm{kcal}$ and $10.4 \mathrm{~g}$ of protein/ day, there was a significant increase in the anthropometric measurements (dry body weight, arm circumference, midarm muscle circumference, waist and hip circumference), laboratory measurements (hemoglobin, pre-dialysis urea, albumin, iron binding capacity), dietary intake [energy, protein, $\mathrm{K}$, calcium $(\mathrm{Ca}), \mathrm{P}$, with a reduction in C-reactive protein (CRP), and MIS, the latter pointing to an improvement in the overall nutritional status [31]. Although this study lacked a control group, this intervention showed a positive impact by improving the nutritional status of the participants [31]. Subsequently, Caetano et al. [32] evaluated the effect of intradialytic meals during the dialysis session for 6 months in HD patients with albumin $\leq 3.8 \mathrm{~g} / \mathrm{dL}$ and compared them with a control group of HD patients with normal albumin concentration. The individual meal included a protein drink with high biological value, plus one egg sandwich, providing in total $420.3 \mathrm{kcal}$ and $31 \mathrm{~g}$ of protein/dialysis session. After 6 months, the group receiving the protein meal showed a significant increase in fat mass as compared to the control group [32]. In another study with a randomized controlled design, conducted in HD patients, protein-enriched meals $(200 \mathrm{~mL}$ of milk and two egg whites), provided during the dialysis session for 3 months and yielding a total of $147.6 \mathrm{kcal}$ and $13.7 \mathrm{~g}$ of protein/dialysis session, indicated that the group receiving the protein-enriched meal showed significant improvement in serum albumin levels when compared to the control group [33]. Finally, in a recently published pilot study, Choi et al. [34] provided meals containing approximately $30 \mathrm{~g}$ protein and $1 / 3$ of the recommended daily $\mathrm{Na}$, $\mathrm{K}, \mathrm{P}$ and liquid to HD patients during 25 consecutive dialysis sessions. They showed that, although no change in nutritional status was observed, the group receiving the meal did not show an increase in symptomatic hypotension events associated with the meals. This finding suggests that there were 
no clinical complications due to eating during the dialysis session [34]. Altogether, these results are supportive of the idea that non-industrialized food products are both plausible and a more likely and affordable strategy towards treating malnutrition in HD patients.

Although our study suffers from the limitation of not planning for an intervention to examine whether the muffins of fine herbs developed an efficient option for treating malnutrition, some important strengths can be listed: Firstly, we investigated, among a group of HD patients, which characteristics they would like to have in a food product in order to align it with the patient's preference and expectations; secondly, we evaluated the safety of these products by assessing their chemical composition; thirdly, the enriched protein muffins were made with affordable ingredients to allow their use among most patients and over a long period of time. Finally, we performed a detailed sensory analysis of the muffins to investigate whether these products were wellaccepted by the patients. When all factors are taken together, we believe that our findings can be used to support other clinical practitioners towards developing food products, in accordance with their local possibilities, and even to test the use of the current food products in other dialysis clinics.

In conclusion, the current study presents the feasible and affordable option of two muffins of fine herbs to function as snacks for dialysis patients. These products were shown to be appropriate for HD patients, with adequate amounts of energy, protein, $\mathrm{K}, \mathrm{P}$ and $\mathrm{Na}$. In addition, the muffins had a high degree of acceptance, as assessed by the sensory analysis. The effectiveness of these products to treat malnutrition remains to be further investigated in a subsequent study.

Acknowledgements We would like to thank the CNPq (National Council for Scientific and Technological Development, Brazil) and the Coordination for the Improvement of Higher Education Personnel (CAPES) for their financial support and for the training of new students. In addition, the present study was supported by the dietitians Juliana Rodrigues and Ana Lucia Pereira who facilitated and assisted the sensory analysis at the dialysis clinic. We would also like to acknowledge DaVita-Medical Services and Renal Treatments for allowing the sensory analysis in the dialysis facilities.

Author contributions The conceptualization of the study and the first draft of the manuscript was carried out by CMA, RFM and JM, but all authors contributed substantially to the study design, development of the study and interpretation of the data collected. All authors critically revised the work and approved the final manuscript.

Funding JM was granted a scholarship from CNPq (National Council for Scientific and Technological Development, Brazil). This study was funded in part by the Coordination for the Improvement of Higher Education Personnel (CAPES) - Finance Code 001. Open access funding provided by Karolinska Institute.

Availability of data and material The data generated and analyzed during the present study are under the domain of the corresponding author and will be made available upon request and evaluation.

\section{Compliance with ethical standards}

Conflict of interest The study protocol was approved by the Local Research Ethics Committee (Pedro Ernesto University Hospital, Rio de Janeiro State University, number 2.259.878).

Ethics approval The study was approved by the Local Ethics and Research Committee.

Informed consent Written informed consent was obtained from each participant before their enrollment in the study.

Consent for publication Patients signed the informed consent form regarding the publication of their collected and analyzed data.

Open Access This article is licensed under a Creative Commons Attribution 4.0 International License, which permits use, sharing, adaptation, distribution and reproduction in any medium or format, as long as you give appropriate credit to the original author(s) and the source, provide a link to the Creative Commons licence, and indicate if changes were made. The images or other third party material in this article are included in the article's Creative Commons licence, unless indicated otherwise in a credit line to the material. If material is not included in the article's Creative Commons licence and your intended use is not permitted by statutory regulation or exceeds the permitted use, you will need to obtain permission directly from the copyright holder. To view a copy of this licence, visit http://creativecommons.org/licenses/by/4.0/.

\section{References}

1. Carrero JJ, Thomas F, Nagy K, Arogundade F, Avesani CM, Chan $M$ et al (2018) Global Prevalence of protein-energy wasting in kidney disease: a meta-analysis of contemporary observational studies from the International Society of Renal Nutrition and Metabolism. J Ren Nutr 28(6):380-392. https://doi.org/10.1053/j. jrn.2018.08.006

2. Carrero JJ, Stenvinkel P, Cuppari L, Ikizler TA, Kalantar-Zadeh $\mathrm{K}$, Kaysen G et al (2013) Etiology of the protein-energy wasting syndrome in chronic kidney disease: a consensus statement from the International Society of Renal Nutrition and Metabolism (ISRNM). J Ren Nutr 23(2):77-90. https://doi.org/10.1053/j. jrn.2013.01.001

3. Fouque D, Kalantar-Zadeh K, Kopple J, Cano N, Chauveau P, Cuppari L et al (2008) A proposed nomenclature and diagnostic criteria for protein-energy wasting in acute and chronic kidney disease. Kidney Int 73(4):391-398. https://doi.org/10.1038/ sj.ki.5002585

4. Ikizler TA, Pupim LB, Brouillette JR, Levenhagen DK, Farmer $\mathrm{K}$, Hakim RM et al (2002) Hemodialysis stimulates muscle and whole body protein loss and alters substrate oxidation. Am J Physiol Endocrinol Metab 282(1):E107-E116. https://doi.org/10.1152/ ajpendo.2002.282.1.E107

5. Pupim LB, Majchrzak KM, Flakoll PJ, Ikizler TA (2006) Intradialytic oral nutrition improves protein homeostasis in chronic hemodialysis patients with deranged nutritional status. J Am Soc Nephrol 17(11):3149-3157. https://doi.org/10.1681/ASN.20060 40413

6. Benner D, Brunelli SM, Brosch B, Wheeler J, Nissenson AR (2018) Effects of oral nutritional supplements on mortality, missed dialysis treatments, and nutritional markers in hemodialysis patients. J Ren Nutr 28(3):191-196. https://doi.org/10.1053/j. jrn.2017.10.002 
7. Tomayko EJ, Kistler BM, Fitschen PJ, Wilund KR (2015) Intradialytic protein supplementation reduces inflammation and improves physical function in maintenance hemodialysis patients. J Ren Nutr 25(3):276-283. https://doi.org/10.1053/j.jrn.2014.10.005

8. Martins AM, Dias Rodrigues JC, de Oliveira Santin FG, Barbosa Brito Fdos S, Bello Moreira AS, Lourenço RA et al (2015) Food intake assessment of elderly patients on hemodialysis. J Ren Nutr 25(3):321-326. https://doi.org/10.1053/j.jrn.2014.10.007

9. Burrowes JD, Larive B, Cockram DB, Dwyer J, Kusek JW, McLeroy S et al (2003) Effects of dietary intake, appetite, and eating habits on dialysis and non-dialysis treatment days in hemodialysis patients: cross-sectional results from the HEMO study. J Ren Nutr 13(3):191-198. https://doi.org/10.1016/s1051 -2276(03)00069-4

10. Kistler BM, Benner D, Burrowes JD, Campbell KL, Fouque D, Garibotto G et al (2018) Eating during hemodialysis treatment: a consensus statement from the International Society of Renal Nutrition and Metabolism. J Ren Nutr 28(1):4-12. https://doi. org/10.1053/j.jrn.2017.10.003

11. Lacson E, Wang W, Zebrowski B, Wingard R, Hakim RM (2012) Outcomes associated with intradialytic oral nutritional supplements in patients undergoing maintenance hemodialysis: a quality improvement report. Am J Kidney Dis 60(4):591-600. https://doi. org/10.1053/j.ajkd.2012.04.019

12. Fouque D, McKenzie J, de Mutsert R, Azar R, Teta D, Plauth M et al (2008) Use of a renal-specific oral supplement by haemodialysis patients with low protein intake does not increase the need for phosphate binders and may prevent a decline in nutritional status and quality of life. Nephrol Dial Transpl 23(9):2902-2910

13. Association Of Official Analytical Chemists International (1995) Official methods of analysis. AOAC International, Arlington, Virgin

14. Watt BM, Merrill AL (1963) Composition of foods: raw, processed, prepared. United States Department of Agriculture (USDA), Washington, DC

15. Adolfo Luts Institute (2008) Physicochemical Methods for Food Analysis Electronic version. https://www.ial.sp.gov.br/resources/ editorinplace/ial/2016_3_19/analisedealimentosial_2008.pdf. Accessed 28 Dec 2019

16. State University Of Campinas (2011) Brazilian Food Composition Table. https://www.nepa.unicamp.br/taco/tabela.php?ativo=tabel a. Accessed 28 Dec 2019

17. Fetter RL, Bigogno FG, de Oliveira FG, Avesani CM (2014) Cross-cultural adaptation to Portuguese of tools for assessing the nutritional status of patients on dialysis. J Bras Nefrol 36(2):176185. https://doi.org/10.5935/0101-2800.20140028

18. Dutcosky SD (2007) Sensory analysis of foods. Champagnat PUC/PR, Curitiba, Parana

19. Fouque D, Veneegor M, ter Wee P, Wraner C, Basci A, Canaud $B$ et al (2007) EBPG guideline in nutrition. Nephrol Dial Transpl 22(Suppl 2):445-487. https://doi.org/10.1093/ndt/gfm020

20. Ikizler TA, Burrowes J, Byham-Gray L, Campbell K, Carrero JJ, Chan W, Fouque D, Friedman D, Ghaddar D, Goldstein-Fuchs J, Kaysen G, Kopple J, Teta D, Yee-Moon Wang A, Cuppari L (2020) KDOQI clinical practice guideline for nutrition in CKD: 2020 update. Am J Kidney Dis

21. Brazil. Ministry of Health (2014) Dietary Guidelines for the Brazilian population. Brasília, Brazil

22. Piccoli GB, Cupisti A, Aucella F, Regolisti G, Lomonte C, Ferraresi $\mathrm{M}$ et al (2020) Green nephrology and eco-dialysis: a position statement by the Italian Society of Nephrology. J Nephrol. https ://doi.org/10.1007/s40620-020-00734-Z
23. Faesel-Aklilu S, Marcus A, Parrot JS, Peters E, Byham-Gray L (2018) Is nutrition specific quality of life associated with nutritional status? J Ren Nutr 28(4):283-291. https://doi.org/10.1053/j. jrn.2017.12.011

24. Kalantar-Zadeh K, Kopple JD, Block G, Humphreys MH (2001) Association among SF36 quality of life measures and nutrition, hospitalization, and mortality in hemodialysis. J Am Soc Nephrol 12(12):2797-2806

25. Rodrigues J, Santin F, Brito FSB, Lindholm B, Stenvinkel P, Avesani CM (2019) Nutritional status of older patients on hemodialysis: which nutritional markers can best predict clinical outcomes? Nutrition 65:113-119. https://doi.org/10.1016/j.nut.2019.03.002

26. Lopes AA, Bragg-Gresham JL, Elder SJ, Ginsberg N, Goodkin DA, Pifer $T$ et al (2010) Independent and joint associations of nutritional status indicators with mortality risk among chronic hemodialysis patients in the Dialysis Outcomes and Practice Patterns Study (DOPPS). J Ren Nutr 20(4):224-234. https://doi. org/10.1053/j.jrn.2009.10.002

27. de Mutsert R, Grootendorst DC, Boeschoten EW, Brandts H, van Manen JG, Krediet RT et al (2009) Subjective global assessment of nutritional status is strongly associated with mortality in chronic dialysis patients. Am J Clin Nutr 89(3):787-793. https:// doi.org/10.3945/ajen.2008.26970

28. Lopes MB, Silva LF, Lopes GB, Penalva MA, Matos CM, Robinson $\mathrm{BM}$ et al (2017) Additional contribution of the malnutritioninflammation score to predict mortality and patient-reported outcomes as compared with its components in a cohort of African descent hemodialysis patients. J Ren Nutr 27(1):45-52. https:// doi.org/10.1053/j.jrn.2016.08.006

29. Spatola L, Finazzi S, Calvetta A, Reggiani F, Morenghi E, Santostasi S et al (2018) Subjective Global Assessment-Dialysis Malnutrition Score and cardiovascular risk in hemodialysis patients: an observational cohort study. J Nephrol 31(5):757-765. https:// doi.org/10.1007/s40620-018-0505-3

30. Xiong J, Wang M, Wang J, Yang K, Shi Y, Zhang J et al (2019) Geriatric nutrition risk index is associated with renal progression, cardiovascular events and all-cause mortality in chronic kidney disease. J Nephrol. https://doi.org/10.1007/s40620-019-00676-1

31. Roy LG, Shetty MS, Urooj A (2013) Effect of nutritional intervention on malnutrition indicators in patients on haemodialysis. J Ren Care 39(1):39-46. https://doi.org/10.111 1/j.1755-6686.2013.12000.x

32. Caetano C, Valente A, Silva FJ, Antunes J, Garagarza C (2017) Effect of an intradialytic protein-rich meal intake in nutritional and body composition parameters on hemodialysis patients. Clin Nutr ESPEN 20:29-33. https://doi.org/10.1016/j.clnesp.2017.04.003

33. Li J, Hou G, Sun X, Chen A, Chai Y (2020) A low-cost, intradialytic, protein-rich meal improves the nutritional status in chinese hemodialysis patients. J Ren Nutr 30(2):e27-e34. https://doi. org/10.1053/j.jrn.2019.03.084

34. Choi MS, Kistler B, Wiese GN, Stremke ER, Wright AJ, Moorthi RN et al (2019) Pilot study of the effects of high-protein meals during hemodialysis on intradialytic hypotension in patients undergoing maintenance hemodialysis. J Ren Nutr 29(2):102-111. https://doi.org/10.1053/j.jrn.2018.06.002

Publisher's Note Springer Nature remains neutral with regard to jurisdictional claims in published maps and institutional affiliations. 